\title{
Cast of Characters
}

Names used for villagers, as well as for the fieldwork site and surrounding villages, are pseudonyms.

Seyyid Ayyub Askari The old and, by 1978-1979, poor, formal head of the Askari taifeh.

Ezzat Wife of Seyyid Ayyub Askari.

Seyyid Ayatollah Askari Son of Seyyid Ayyub Askari; shopkeeper; one of the village peacemakers. ${ }^{1}$

Seyyid Ali Askari Son of Seyyid Ayyub; guard at the gravel pit.

Akhtar Askari Wife of Seyyid Ali.

Seyyid Morteza Askari Son of Seyyid Ali; supported the peasants or people's faction against his father's cousin, Seyyid Ibn Ali.

Seyyid Kazem Askari Son of Seyyid Ayyub Askari; gifted political analyst; usually unemployed, apparently due to back problems.

Seyyid Mostafa Askari Son of Seyyid Ayyub Askari; often away from the village on his job with the Office of Malaria Control.

Sakineh Askari Younger daughter of Seyyid Ayyub Askari.

Seyyid Ibn Ali Askari Son of a deceased brother of Seyyid Ayyub Askari; richest and most influential person from Aliabad; became largest landowner of the village when he bought village land before land reform; lived in Shiraz in 1978-1979. 
Seyyid Yaqub Askari Brother's son of Seyyid Ayyub Askari and Seyyid Ibn Ali Askari's brother; de facto head of the village and main government representative in Aliabad.

Rezvan Wife of Seyyid Yaqub Askari; not a native of Aliabad.

Seyyid Muslem Askari Son of Seyyid Yaqub Askari; important figure in village politics and economics.

Mina Amini Wife of Seyyid Muslem Askari and daughter of Mashd Yusef Amini.

Haj Ali Reza Amini Son of deceased sister of Seyyid Ayyub Askari and Mashd Yusef Amini's brother; right-hand man of the Askari brothers.

Mashd Yusef Amini Brother to Haj Ali Reza Amini and an important supporter of the Askari brothers.

Mohammad Amini Son of Mashd Yusef Amini; teacher and important young leader of the revolutionary movement in the village.

Naser Amini Son of Mashd Yusef Amini and Mohammad Amini's brother; policeman in Shiraz; married to daughter of the kadkhoda, Hamid Jehangiri; important supporter of the Askari brothers.

Haj Aqa Amini Another brother of Haj Ali Reza and Mashd Yusef Amini; supporter of the Askari brothers. ${ }^{2}$

Fatimeh Askari Daughter of a deceased brother of Seyyid Ayyub; sister of Askari brothers Seyyid Ibn Ali and Seyyid Yaqub.

Roqayeh Askari Younger daughter of Fatimeh Askari.

Ehteram Askari Daughter of a deceased daughter of Fatimeh Askari.

Jafar Askari Younger son of Fatimeh Askari.

Seyyid Enayat Askari older son of Fatimeh Askari.

Rana Askari Wife of Seyyid Enayat Askari; leader of the social circle of seyyid women.

Seyyid Asadollah Seyyid Ibn Ali Askari's and Seyyid Yaqub Askari's brother; in charge of Askari gasoline pump and natural gas installation controlled by the Askari brothers.

Seyyid Rahman Askari Son of another deceased brother of Seyyid Ayyub Askari; employed as guard in gravel pit partially owned by Seyyid Ibn Ali and his supporter during the post-Revolution uprising against him. 
Seyyid Akbar Askari Distant relative of the Askari brothers; was a shoemaker and trader; began working for a nearby factory in 1979; capitulated to pressure from the anti-Ibn Ali faction, including his wife's father, and joined their side.

Seyyid Husein Askari Local mulla; distant relative of the Askari brothers though he did not have much contact with them.

Haidar Amini Son-in-law and former partner of Seyyid Ayyub Askari; trader and former sharecropper.

Behnam Amini Son of Haidar Amini; employee of the Office of Electricity in Shiraz.

Hushang Amini Son of Haidar Amini; accepted at Tehran University but returned to Aliabad during university strikes in support of the Revolution.

Kurosh (Cyrus) Amini Son of Haidar Amini's brother; revolutionary leader among the local young men; stabbed in a crucial local incident before the Revolution; married Haidar Amini's only daughter.

Mohsein Saedi Son of Kurosh Amini's mother's brother; also wounded in the knifing incident.

Mehdi Married to the sister of Kurosh Amini and his assailant in the knifing incident.

Haj Khodabakhsh Shopkeeper and husband of Ali Reza’s and Mashd Yusef Amini's sister as well as their supporter; brother of Mehdi's mother.

Shaikh Karim Kazemi Leading religious figure and head of proMosaddeq and pro-Tudeh sympathizers in Aliabad; died not long after the Mosaddeq period in the 1950s.

Shaikh Rahim Kazemi Son of Shaikh Karim Kazemi; not actually a Shaikh but a retired school teacher who, with his father, was active in supporting Mosaddeq; important figure in pro-revolutionary village activity; initially perhaps the main leader in the local movement against Seyyid Ibn Ali some months after the Revolution.

Haj Manuchehr Zamani Last kadkhoda before the 1962 land reform; lived in Shiraz in 1978-1979.

Mulla Jamshid Ajami Former kadkhoda; died shortly before 1978. 
Haj Ali Hemmat Hashemi Important leader of the pro-Mosaddeq movement in the village; lost his land during the peasant strike; called upon to perform religious functions in the village; important leader in the movement against Seyyid Ibn Ali after the Revolution.

Haj Sadrollah Hashemi Owner of successful local construction company; supporter of the revolutionary movement and the post-Revolution movement against Seyyid Ibn Ali.

Haj Fazlollah Rezai Trader from a family that fought against the Askaris during the land reform struggles; active supporter of the Revolution and a leader in the anti-Seyyid Ibn Ali movement after the Revolution.

Haj Baqer Rezai Died during the land reform struggle. Though his death was accidental, the Rezais blamed Seyyid Ibn Ali Askari. According to villagers, the continuing bitter enmity of the Rezais toward the Askaris was due to Haj Baqer's death — that and land.

Esmat Ajami Seamstress and young widow; her in-laws, the Saedis, were active in the land reform struggle and leaders in the postRevolution movement against Seyyid Ibn Ali; articulate supporter of the Revolution and the anti-Seyyid Ibn Ali faction; the author's closest friend in Aliabad.

Haj Hamdullah Saedi Brother-in-law of Esmat Ajami; from the Saedi family active in the land reform struggle and post-Revolution movement against Seyyid Ibn Ali.

Hamid Jehangiri Kadkhoda during the fieldwork period.

Majid Jafari From a family active in the struggle against Seyyid Ibn Ali during the land reform conflict; refused to join the movement against Seyyid Ibn Ali after the Revolution because his wife was related to him.

Mashd Musa Saedi From a family active in the land reform resistance against Seyyid Ibn Ali; has since joined the village administration as a member of the village council and president of the cooperative. 